\title{
발표논문
}

\section{가람의 한국민속적 요소와 의미}

- 가람각을 중심으로

오인 I 중앙승가대학교 수행학부 조교수

목차

\section{1. 들어가기}

\section{2. 경전에 보이는 가람과 가람신}

1) 가람과 도량

2) 가람18신과 마후라가왕

\section{3. 한국의 가람각}

1) 가람각과 토지당

2) 한국 가람각의 역사와 현황

(1) 통도사 가람각

(2) 표충사 가람각

(3) 해인사 국사단

3) 한국 가람각의 한국민속적 요소와 의미

\section{4. 나가기}

참고문헌 


\section{1. 들어가기}

외래종교와 토착종교와의 습합은 어떠한 문화적 변용을 초래하는가?

이는 두 분야 연구자들의 공통된 연구주제일 것이다.

불교와 한국민속은 어떠한 관계를 형성하고 상호보완하며 전승되어 온 것인가. 이에 대해서 홍윤식은 불교민속, 민속불교라는 두 가지 개 념을 설정하고, "이 양자가 구분되는 것은 전자는 불교적 교리체계 속 에 또는 교리체계에 의하여 민간신앙적 요소와 그 습속 등을 수용하고 있는 것이라면, 후자는 민간신앙의 체계 속에 불교를 수용하고 있지 못 하는데 차이점이 발견된다." ${ }^{51)}$ 고 하였다.

본 논문은 가람과 한국민속과의 접점을 가람각으로 상정하였으며, 이를 불교민속학적인 입장에서 고찰하고자 한다.

가람각에 대한 연구성과는 동아시아 불교권에서 중국과 일본을 중 심으로 상당히 축적되어 있다. ${ }^{52)}$ 반면, 한국은 선행연구가 전무하며, 관

51) 홍윤식 외『불교민속학의 체계』,p.9

52) 三山進「伽藍神像考-鎌倉地方の作品を中心に」『MUSEUM』200, 東京国立博物館, 1967년

乼德忠「台湾の土地神信仰」『宗教研究』44-4, 日本宗教学会, 1971년

寉德忠「土地神と土帝君」『宗教研究』45-3, 日本宗教学会, 1972년

洼徳忠「東アジアの土地神信仰」『宗教研究』46-3, 日本宗教学会, 1973년

酒井忠夫「中国江南史上の道教信仰一特に土地神をめぐる文化の地域性」『仏教の歴史と文 化』同朋舍, 1980년

中世古祥道「招宝七郎大権修理菩薩について」『宗学研究』35, 曹洞宗総合研究センター, 1993년 加納宽「タイ中央部都市土地神信仰の変遷にみる民衆文化変容一祠・神体の形態变遷を中心に」

『東南アジア史学会会報』61, 東南アジア史学会, 1994년

二階堂善弘「祠山張大帝考-伽藍神としての張大帝」『關西大學中國文學會紀要』28, 関西大 学, 2007년

田中知佐子「建長寺伽藍神像をめぐる一考察」『仏教芸術』301, 毎日新聞社, 2008년

二階堂善弘「民間信仰における神形象の変化についてー華光大帝と招宝七郎を例に」『東アジ ア文化交渉研究』1, 関西大学, 2008년

広瀬良文「中世禅宗の土地伽藍神について一建長寺·永本寺像を中心に」『印仏学』62-2, 2014년 
련한 글은 답사기행문이나 짧은 보고서 정도이다. ${ }^{53)}$

한국의 가람각에 대한 연구부진은 한국불교의 문화적 현상에서 기 인하는 것이다. 가람각은 몇 곳의 고찰에만 세워져 있으며, 대부분의 사찰에서는 전각의 존재조차 인식하고 있지 못하고 있는 실정이다.

본 연구의 목적은 한국 가람각의 유래와 역사적 변화, 그리고 현황 을 파악하고, 나아가, 한국민속과의 관련성, 특히 민속적 요소와 의미 에 대하여 고찰하고자 한다.

연구방법은 문헌적 검토와 현장답사, 그리고 대담 등을 통할 것이다. 문헌적 검토는, 가람, 도량, 가람각 등의 용어의 출전과 의미를 경전 에서 도출하고, 가람각의 유래 및 위격 등에 대해서는 사료를 통하여 살펴보고자 한다.

현장답사는 해인사와 표충사, 통도사를 대상사찰로 하였으며, 월정 사는 제외하였다. 왜냐하면 앞에서도 밝혔듯이, 본고는 불교민속적인 입장에서 진행되는 연구로, 월정사는 민속불교적인 입장의 연구대상 이라는 판단 때문이다.

문헌기록이 없는 경우에는 관계자나 사중 스님들과의 대담을 통하 여 가람각의 역사와 위격에 대하여 파악하고자 한다.

2 장에서는 경전에 보이는 가람의 정의와 가람신에 대하여, 3 장에서 는 한국의 가람각에 대하여 서술하고자 한다. 세부적으로는 통도사, 표 충사, 해인사 가람각의 유래와 현황을 살펴본 후, 한국 가람각의 한국 민속적 요소와 의미에 대하여 고찰할 것이다.

53) 이기선「가람각」『불교』 672 , 월간불교사, 2011년 10월호 통도사발행「가람각」『월간 보궁』384, 2013년 11월호 


\section{2. 경전에 보이는 가람과 가람신}

\section{1) 가람과 도량}

가람의 사전적인 의미는 "승가람마, 승가람, 아람 등이라고 하며, 중원, 원, 사원 등으로 한역하며, 범어와 한역을 겸하여 승원이라고도 한다. 원래 출가자들이 공동으로 생활할 수 있는 장소 등의 공간을 가리키는 말이었으나, 뜻이 변하여 토지와 건축물을 모두 포함하는 사원의 총칭 이 되었다." ${ }^{54)}$ 고 한다.

일반적으로 한국불교에서는 '가람' ‘도량 '경내' 등의 용어를 구분하 지 않고 '사찰'이라고 하는 동일한 의미로 사용하고 있다. 그러나, 경전 에서는 가람과 도량을 구분하여 설명하고 있으며, 교리적으로도 분명 한 차이점을 지니고 있다. 이에 대하여 간단히 살펴보고자 한다.

『법원주림』에서는 가람을 다음과 같이 설하고 있다.

대개 가람이란, 옛적 서역에 금을 깔아서 처음으로 복의 터를 마련하였고, 동천 에 집을 지어 마침내 깨끗한 업을 빌었다. 그러므로 보탑에는 그 광명을 모으고 정 사에는 그 형상을 그려 삼천세계에 두루 채우고 1만 년 동안 맡아 지킨다. 고해를 건너는 배가 되고 신근의 줄기가 되어 그것을 보면 발심하고 그것을 보고는 돌아가 기를 잊고 복을 증익시키고 선함을 내나니, 이것을 가람이라 칭한다. ${ }^{55}$

가람은 수달장자의 기원정사로부터 시작되었으며, 가람에는 탑과

54) 『가산불교대사림』권1, p.34

55)『法苑珠林』권 39 ( 대정장』53, p.591상) 
전각이 있으며, 신심으로 발심하며, 선한 마음을 내는 곳이라고 정의 하고 있다.

또한, 가람은 다른 명칭을 갖는데, 이는 의미에 따른 것이라고 한다.

고덕의 사고에 많은 명칭이 있다. 혹은 도량이라 하니, 생이 없는 조정이란 뜻이 다. 혹은 절이라 하니, 공정이란 뜻이다. 혹은 정주사청정하게 주하는집), 혹은 법 동사법을 함께 하는 집), 혹은 출세간사(세간을벗어나는 집), 혹은 정사, 혹은 청정 무극원(청정함이 끝없는 동산, 혹은 금강정찰(금강처럼 청정한 국토), 혹은 적멸도 량, 혹은 원리악처(악을 멀리 떠나는 곳라고 한다. 이것은 모두 그 뜻을 따라 이름 을지은 것으로 각각 나타냄이 있다.50)

위의 이명 가운데, 도량을 '생이 없는 뜰'이라고 하는 것은, '생사가 없 는 곳, 즉 부처님의 열반적정을 의미하는 것이다.

한편, 도량은 보리도량, 혹은 보리량이라고도 하여, 부처님이 성도하 신 장소를 말하기도 한다.57) 정각 도량에 관해서는 『화엄경』「세간 정안품 $\lrcorner^{58}$ 에 설하여져 있다.

어느 때 부처님께서는 마갈제국의 적멸도량에서 처음으로 정각을 이루셨다. 그 땅은 금강으로 되어 장엄과 청정함을 갖추었고 온갖 보배와 꽃들로 장식하였으며, 가장 묘한 보배 바퀴는 원만하고 청정하며 한량없는 묘한 빛깔로 갖가지로 장엄하

56) 『法苑珠林』권39( 대정장』53, p.591상)

古德寺誥乃有多名 或名道場即無生廷也 或名為寺即公廷也 或名淨住舍 或名法同舍 或名出世間舍 或名精舍或名清淨無極園或名金剛淨刹或名漃隇道場 或名遠離亞處 或名親近善處並隨義立各有所 表

57) 『망월불교대사전』권4, p.3897

58) 60 화엄경』이다. 불타발타라가 동진시대, 418 년에 번역을 시작하여 422 년에 완료하였다. 
여 마치 큰 바다와 같았다. 보배로 된 당기와 번기와 일산들은 광명이 번쩍이고, 묘 한 향과 화만은 그 주위를 둘렀ㅆㅆㄷㅏ. 칠보로 된 그물로 그 위를 덮고 한량없는 보배 를 비오듯 내리어 변화가 자재하며 온갖 보배 나무는 꽃과 잎이 무성하고 빛났다. 부처님의 신력으로 도량은 넓고 깨끗하며, 광명이 두루 비쳐 모두가 기특하고 온 갖 보배 무더기와 한량없는 선근으로 도량을 장엄하였다. ${ }^{59)}$

정각 도량은 부처님의 신력으로 넓고 깨끗하며, 부처님의 한량없는 선근공덕으로 도량을 장엄하는 것이다. 이 경문을 통하여, 가람과 도량 이 교리적으로 동일하지 않음을 확인할 수 있었다.

그런데, 『법화경』「여래신력품」에서는 “도량, 모든 부처님께서 는 여기에서 아녹다라삼먁삼보리를 얻으셨으며, 모든 부처님께서는 여기에서 법륜을 굴리셨으며, 모든 부처님께서는 여기에서 반열반에 이르셨다.”(0)고 하여, 도량에서 정각과 전법, 그리고 열반이 모두 이루 어졌다고 설한다.

이상으로 가람과 도량에 대하여간단히 고찰한 결과, 가람은 사원 전 체를 지칭하고, 도량은 부처님을 봉안한 법당과 법당 주변이라고 정의 할 수 있을 것이다. 경내가 상 - 중 - 하노전으로 삼분되어 있는 통도사 를 예로 든다면, 상로전 구역이 도량, 상 · 중 · 하노전 전체는 가람이 되는 것이다.

59)『大方廣佛華嚴經』권1「世間淨眼品」( ${ }^{\circledR}$ 대정장』9, p.395상)

一時佛在摩竭提國寂滅道場始成正覺其地金岡具足嚴淨 衆寶雜華以為莊飾上妙寶輪圓滿清淨 無量 妙色種種莊嚴 唒如大海寶幢幡蓋光明照耀 妙香華鬒周匝圍遶七寶羅網彌覆其上 雨無盡寶顯現自在 諸雜寶樹華葉光茂 佛种力故 令此場地廣博嚴淨 光明普照一切奇特妙寶積聚 無量善根莊嚴道場

60)『妙法蓮華經』권6「如來神力品」（『대정장』9, p.52상)

道場 墸佛於此得阿犀多羅三藐三菩提 諸佛於此轉于法輪 諸佛於此而般涅槃 


\section{2) 가람18신과 마후라가왕}

가람신은 가람을 수호하는 신을 말하는데, 수가람신, 호가람신, 호승가 람신, 사신(1), 승가람신(2)이라고도 한다.

『대장엄론경』에 “그때 비구니의 가람을 지키던 천신이 구담미 비 구니가 열반에 들려고 하는 것을 알고서 슬피우니, 그 눈물이 비구니들 의 옷 위에 떨어졌다."(3)고 하여, 가람신에 대하여 언급하고 있다. 그러 나, 가람신의 역할을 하고 있는 천신의 이름은 보이지 않는다.

그러나, 다른 경전에는 가람신을 대표하는 18 신이 있다고 하며, 가람 18 신의 이름을 밝히고 있다. A-1『칠불소설신주경』, A-2 『다라니잡 집』, A-3『법원주림』, A-4 『제경요집』, A-5『석씨요람』이다.

\section{A-1}

호승가람신이 18신이 있는데 저마다 그 이름이 다르다. 첫 번째는 이름이 미음이 요, 두 번째는 범음이며, 세 번째는 천고요, 네 번째는 교묘이며, 다섯 번째는 탄미 요, 여섯 번째는 광묘이며, 일곱 번째는 뇌음이요, 여덟 번째는 사자음이며, 아홉 번째는 묘미요, 열 번째는 범향이며, 열한 번째는 인음이요, 열두 번째는 불노이며, 열세 번째는 탄덕이요, 열네 번째는 광목이며, 열다섯 번째는 묘안이요, 열여섯 번 째는 철청이며, 열일곱 번째는 철시요, 열여덟 번째는 변관이다. ${ }^{61)}$

61）守伽藍神, 護伽藍神, 護僧伽藍神, 寺神とい5 ${ }^{\circ}$ (『望月仏教大辞典』권1, p.480)

62)『大莊嚴論經』권14(『대정장』4,p.333상); “佛所說神呪經』권4("대정장』21, p.557하) 『陀羅尼雜集』권6(『대정장』21,p.612상); 『集諸經禮擮儀』 권상 (『대정장』47, p.458상) “僧伽藍神”

63) 『大莊嚴論經』권14 (『대정장』4, p.333상) 爾時尼僧伽藍神 知矍曇彌欲入涅槃 悲泣涕淚墮比 丘尼衣上 


\section{A-2}

호승가람신 여기에는 열여덟 명이 있는데 저마다 그 이름이 다르다. 미음 범음 천 고 교묘 탄미 마묘 진음 사자음 묘탄 범향 인음 불노 탄덕 광목 묘안철시 변관 조 비이다. ${ }^{65)}$

\section{A-3}

『칠불경』 에서 말하였다. 승가람을 수호하는 18신이 있다. 첫 번째는 이름이미음 이요, 두 번째는 범음이며, 세 번째는 천고요, 네 번째는 탄묘이며, 다섯 번째는 탄 미요, 여섯 번째는 마묘이며, 일곱 번째는 뇌음이요, 여덟 번째는 사자이며, 아홉 번째는 묘탄이요, 열 번째는 범향이며, 열한 번째는 인음이요, 열두 번째는 불노이 며, 열세 번째는 탄덕이요, 열네 번째는 광목이며, 열다섯 번째는 묘안이요, 열여섯 번째는 철청이며, 열일곱 번째는 철시요, 열여덟 번째는 변시이다. 이러한 신이 있 어서 절을 수호한다. 절에 사는 사람도 스스로 써 게으름이 없게 하라. 현재의 과 보를 불러올까 두렵다. ${ }^{60)}$

64)『佛所說神呪經』권4(『대정장』21, p. 557하)

護僧伽藍神斯有十八人各各有別名一名美音二名梵音三名天鼓四名巧妙 五名歎美 六名廣妙 七名雷音八名師子音九名妙美十名梵響十一名人音十二名佛奴十三名歎德十四名廣目十五 名妙眼十六名徹聽十七名徹視十八名遍觀

65)『陀羅尼雜集』권6(『대정장』21, p.612상)

護僧伽藍神斯有十八人 各各有別名美音梵音天鼓巧妙嘆美 摩妙 震音 師子音妙嘆梵響人音 佛奴 歎德 廣目 妙眼 徹視 遍觀 照卑

66)『法苑珠林』권39「營造部第二」(『대정장』53,p.593상)

七佛經云 護僧伽藍神斯有十八神一名美音二名梵音三名天鼓 四名歎妙 五名歎美 六名摩妙七 名雷 音八名師子九名妙歎十名梵響十一名人音十二名佛奴十三名歎德十四名廣目十五名妙 眼十六名幑聽十七名徹視十八名遍視 寺既有神護居住之者亦宜自勱不得惰㤐恐招現報也 


\section{A-4}

『칠불경』 에서 말하였다. 승가람을 수호하는 18신이 있다. 첫 번째는 이름이 미음 이요, 두 번째는 범음이며, 세 번째는 천고요, 네 번째는 탄묘이며, 다섯 번째는 탄 미요, 여섯 번째는 마묘이며, 일곱 번째는 향음이요, 여덟 번째는 사자이며, 아홉 번째는 묘탄이요, 열 번째는 범향이며, 열한 번째는 인음이요, 열두 번째는 불노 이며, 열세 번째는 탄덕이요, 열네 번째는 광목이며, 열다섯 번째는 묘안이요, 열 여섯 번째는 철청이며, 열일곱 번째는 철시요, 열여덟 번째는 변시이다. 이러한 신 이 있어서 절을 수호한다. ${ }^{67)}$

\section{A-5}

『칠불경』에서 말하였다. 승가람을 수호하는 18신이 있다. 첫째 미음, 둘째 범음, 셋째 천고, 넷째 탄묘, 다섯째 탄미, 여섯째 마묘, 일곱째 뇌음, 여덟째 사자, 아홉째 묘탄, 열째 범향, 열한 번째 인음, 열두 번째 불노, 열세 번째 탄덕, 열네 번째 광목, 열다섯 번째 묘안, 열여섯 번째 철청, 열일곱 번째 철시, 열여덟 번째 변시이다. ${ }^{68)}$

위의 5 종 경전에서 설하는 가람 18 신의 명칭을 간단히 〈표1〉로 정리 하였다.

67) 『諸經要集』권3(『대정장』54,p.23상)

七佛經云 護僧伽藍神 斯有十八神一名美音二名梵音三名天鼓 四名歎妙 五名歎美 六名摩妙七 名香音八名師子九名妙歎十名梵響十一名人音十二名佛奴十三名歎德十四名廣目十五名妙 眼十六名徽聽十七名徽視十八名遍視 寺既有种護

68)『釋氏要覽』권상 ( 대정장』54,p.263하)

護伽藍神 七佛經云 有十八神護伽藍一美音二梵音三天鼓 四歏妙 五歎美 六摩妙 七雷音八師子 九妙歎十梵響十一人音十二佛奴十三歎德十四廣目十五妙眼十六徽聽 十七徽視十八遍視 


\begin{tabular}{c|c|c|c|c|c|c|c|c|c|c|c|c|c|c|c|c|c|c}
\hline 경명 & 1 & 2 & 3 & 4 & 5 & 6 & 7 & 8 & 9 & 10 & 11 & 12 & 13 & 14 & 15 & 16 & 17 & 18 \\
\hline 칠 & 미음 & 법음 & 천고 & 교묘 & 탄미 & 광묘 & 뇌음 & 사자음 & 묘미 & 범향 & 인음 & 불노 & 탄덕 & 광목 & 묘안 & 철청 & 철시 & 변관 \\
\hline 다 & & & & & & 마묘 & 진음 & & 묘탄 & & & & & & & 조비 & & \\
\hline 법 & & & 탄묘 & & 마묘 & & 사자 & 묘탄 & & & & & & & & & 변시 \\
\hline 제 & & & 탄묘 & & 마묘 향음 & 사자 묘탄 & & & & & & & & & 변시 \\
\hline 석 & & & 탄묘 & & 마묘 & & 사자 묘탄 & & & & & & & & & 변시 \\
\hline
\end{tabular}

위의〈표1〉은 경전성립연대를 기준하여 『칠불소설신주경』(이후

『칠불경』)을 기본으로 하였다. 성립연대를 살펴보면『칠불경』은 동진시대(317-420), 『다라니잡집』은 6세기 중엽, 『법원주림』은 7세 기, 『제경요집』은 659년에 편찬되었으며, 『석씨요람』은 송대의 저 서이다.

〈표1〉을 통해서, 4, 6, 7, 8, 9, 16, 18번의 가람신명이 다름을 알 수 있다. 『다라니잡집』을 제외한 『법원주림』『제경요집』『석씨요 람』은 『칠불경』 에서 인용하였다고 밝혔음에도 불구하고『칠불 경』의 신명과 일치하지 않는다. 특히, 『다라니잡집』은 $16,17,18$ 의 순서도 바뀌어 있으며 16번을 '조비'라고 기록하고 있다. 또한 7번은 진 음, 향음으로 가장 많은 변화를 보이고 있다.

한편, 『석씨요람』 에는 가람신이 18신인 이유에 대하여 설명하고 있는데, 모든 신에게는 수많은 권속이 있어 역할을 분담할 수 있기 때 문이라고 한다.

도세법사가 말하기를, 사원에는 18신이 있어서 보호한다. (중략) 묻기를 세계 안 에는 가람이 무수히 있는데, 어찌하여 다만 18신이 능히 보호한다고 합니까. 답하 기를 일체의 신은 모두 무수한 권속이 있기 때문에 역할을 나누어 보호하여도 무 방한 것이니라. ${ }^{69)}$ 
한편, 『신화엄경론』에는 경문A의 가람 18 신과는 다른 마후라가왕 을 가람신이라고 설하고 있다. B-1은 『신화엄경론』 권 $11, \mathrm{~B}-2$ 는 『신 화엄경론』 권33의 내용이다.

\section{$\mathrm{B}-1$}

제 4 마후라가왕은 대망이라 하고 또는 대복이라 한다. 라가는 흉복행이다. 정진바 라밀을 주재한다. 흉복행이란 즐거운 법을 구하여 나아가서 사람들을 이롭게 하 고, 업드림으로써 아만을 여의고 겸손함을 밝힌 것이다. 이는 정진 의 뜻이다. 일체 처회향에 이르는 것을 밝힌 것이니, 6 도의 어디에도 들어가지 않는 곳이 없다. 그 리고 이것은 가람을 수호하는 신이니, 능히 법을 수호하기 때문이다. ${ }^{70)}$

\section{B-2}

마후라가왕이란 것은 배로 다니는 큰 이무기의 종류이다. 형상을 취하여 법으로 표현하면, 가슴과 배로 다니는 것은 공경의 의미이며, 이는 승가람을 수호하는 신 이다. ${ }^{71}$

마후라가왕은 이무기나 큰 구렁이의 형상을 하고 있다. 마후라가왕 의 흥복행은 자신을 낮춤으로서 아만심을 여의고, 겸손과 공경을 나타 내며, 중생에게는 이로움을 준다고 한다. 바로 이것이 마후라가왕 가람

69)『釋氏要覽』권상 ( 대정장』54, p.263하)

道世法師云 寺院既有十八神蒦 (중략) 或問世界之內伽藍無數 何只十八神而能遍蒦耶 答一切神皆有 無數春屬即是分任守護也無妨

70)『新華嚴經論』권11( ${ }^{\circledR}$ 대정장』36, p.791c)

第四摩睺羅伽王 此云大蟒也 亦云大腹 羅伽云胸腹行也 主精進波羅蜜 胸腹行者 明趣求樂法利人 匍 匐 離慢謙敬也 是精進義也 明至一切處迴向也六道之生無處不入 此是守護伽藍神能護法故

71) 新華嚴經論』권33(『대정장』36, p.949b)

摩睺羅伽王者 此是腹行大蟒之類 取像表法 以胸腹行是恭敬義 此是守護僧伽藍种

발표논문 | 가람의 한국민속적 요소와 의미 - 가람각을 중심으로 63 
신이 행하는 정진바라밀인 것이다.

마후라가왕도 많은 권속이 있다. 경전에는 각각의 마후라가왕의 공 능이 설하여져 있으나, 본고에서 그에 대한 서술은 생략하고자 한다.

또 한량없는 마후라가왕이 있었으니, 이른바 선혜 마후라가왕, 청정 위음 마후라가왕, 승혜장엄계 마후라가왕, 묘목주 마후라가왕, 여등당 위중소귀 마후라가왕, 최승광명당 마후라가왕, 사자억 마후라가왕, 중 묘장엄음마 마후라가왕, 수미견고 마후라가왕, 가애악광명 마후라가 왕 들이었다. ${ }^{72)}$

결론적으로, 경전에서 설하는 가람신은 가람18신과 마후라가왕 가 람신의 두 부류가 있다. 그런데, 두 부류의 가람신의 공능이 서로 다르 다.

『석씨요람』의 가람18신은 "거주하는 자는 스스로 힘써 게으름이 없게 하라. 현재의 과보를 초래할까 두렵다." ${ }^{73)}$ 고 하여, 수행자들의 나 태함을 경책한다. 반면, 『신화엄경론』의 마후라가왕 가람신은 아만 을 여의고 겸손함 정진바라밀을 행할 것을 강조한다.

논자는 『석씨요람』 의 가람 18 신에는 민속적 요소가 개입되어 있다 고 생각한다. 왜냐하면, 수행자들을 경책하고 있지만, 민속신앙의 특징 인 경계심과 빠른 과보를 말하는 현보現報를 강조하고 있기 때문이다.

72) 『大方廣佛華嚴經』권1 ( 대정장』10,p.4상)

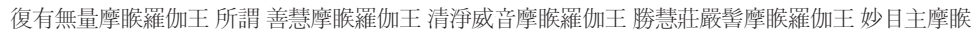
羅 伽王 如燈幢為眾所歸摩睺羅伽王 最勝光明幢摩睺羅伽王師子臆摩睺羅伽王 眾妙莊嚴音摩䀢羅伽 王須 彌堅固摩䀵羅伽王 可愛采光明摩䐅羅伽王

73)『釋氏要覽』권상 ( 대정장』54,p.263하)

居住之者亦宜自勵不得急惰為非 恐招現報耳 


\section{3. 한국의 가람각}

\section{1) 가람각과 토지당}

가람각은 가람신을 모신 전각을 말한다. 가람전(伽藍殿舟, 가람당伽藍 堂75), 가람신묘伽藍神廟(7), 가람단(伽藍壇》)으로도 불리운다. 하지만, 경전에 가람각이라는 용어는 보이지 않는다.

중국과 일본의 선종사원에서는 가람당이라는 용어를 주로 사용하였 다. 『석씨요람』 에 “중국 사원에는 (중략) 가람신묘를 세운다. (혹자는 이것이 지금의 토지묘라고 한다)"78)고 하여, 가람당과 토지당의 선후관 계를 설명하고 있는 것 같지만, 사실, 송나라 때 선종사원에서는 가람 당과 조사당을 법당의 좌우에 배치하고, 가람당을 토지당, 토지묘라고 도 칭하였던 것이다. 이는 토지신을 가람수호신으로 삼고 제사를 지냈 기 때문이라고 한다. ${ }^{99}$

가람당과 토지당의 관계를 선원청규 중「사절」과 관련한 내용을 통하여 간단히 살펴보자. C-1 『환주암청규』, C-2 『칙수백장청규』 이다.

74)『神僧傳』권5( 대장경』50,p.982중); 法華經傳記』권3( 대장경』51,p.60상) 외

75)『法苑珠林』권38(『대장경』53,p.583상); 『宋高僧傳』권19 (『대장경』50,p.832상);

吆住庵清規』(『만자속장경』 $63, p .573$ 하) 외

76) 『釋氏要覽』 권하( 대정장』54,p.303중); 『四分律刪繁補閶行事鈔』권하( “대장경』40,p.136상);

『宋高僧傳』권19("대장경』50, p.832상) 외

77) 가람단이라는 용어는 송나라 지반의 저술『法界聖凡水陸勝會修齋儀軌』 권2 ( 만자속장 경』74, p.796상)에만 보인다.

78) 釋氏要覽』 권하 ( 대정장』54, p.303중) 中國僧寺 (중략) 立伽藍神廟 (或是今土地廟也)

79) 『가산불교대사림』권1, p.37 


\section{C-1}

사절은 결제, 해제, 동지, 정초이다. (중략) (4월)14일 만참시에 토지(당) 앞에서 염 송하고 공양을 가람당에 진설한다. 90 일의 동안 수호하여 수증의 공을 닦게 한 것 에 대한 보답인 것이다. ${ }^{80)}$

\section{C-2}

무릇 사절 때가 되면, 하루 앞서 오후에 토지당에 공양을 진설하고, 향과 촛불과 대 궤와 향로와 병을 배열한다. ${ }^{81)}$

『환주암청규』 에는 토지당과 가람당이 병립하고 있다. ${ }^{82)}$ 그런데, 『칙수백장청규』 에는 토지당만 있고, 가람당은 기록되어 있지 않다. 『환주암청규』는 연우4년(1317), 『칙수백장청규』는 지원2년(1338) 에 편찬된 동시대의 문헌이다. 그럼에도 불구하고 가람당에 대한 기록 의 유무를 보이고 있는 것이다.

한편, 『칙수백장청규』 에는 토지당이 법당과 함께 매우 중요한 전 각이었음을 시사하고 있다.

주지장의「염송」시에 “조당, 토지당, 대전에 이르면 분향한다." ${ }^{83)}$ 주지로 임명받아 총림에 들어가는 「입원」시에 "괘탑이 끝나면 불전

80) 『幻住庵清規』(만자속장경』63, p.573하)

謂四節者即結制解制 冬至歲朝是也 (중략) 十四日晚參時土地前念誦排例供養伽藍堂 用酬守護九 旬修證之功

81) 『勅修百丈清規』권7 (『대정장』 48, p.1152중)

四節土地堂念誦 凡遇節 先一日午後土地堂嚴設供養排香燭臺几爐瓶

82) 또한, 『幻住庵清規』에 “初二十六 伽藍堂諷經回向” ( 만자속장경』63,578c)이라고 하여, 가람 당에서 풍경법회 회향을 가졌던 것도 확인된다.

83) 『勅修百丈清規』권2(『대정장』 48, p.1121상)「念誦」到祖堂土地堂大殿 燒香僼拜 
에 이르러 분향하고, 이어 토지당과 조당에 분향한다." ${ }^{84)}$ 또한, 사미가 득도할 때에도 "행당으로부터 발을 울리면서 삭두인을 데리고 나온다. 토지당, 조당, 불전에 분향삼배한다." ${ }^{85)}$ 고 하여, 사중에 큰 행사나 법회 가 있을 때, 반드시 분향예배하는 전각이었다.

토지당은 일본의 선종사원으로 전승되었다. 특히, 중국 오산의 하 나인 만수사 가람을 모방해서 창건한 건장사에는 현재도 토지당이 존 재하고 있다.「건장사가람지도建長寺伽藍指図」에 의하면 토지당이 조사당과 함께 불전의 좌우에 독립된 당우로 배치되어 있음을 알 수 있 다. 그러나, 현재는 불단을 향하여 오른편의 뒤쪽에 토지당이라는 단 이 마련되어 있는데, 이는 몇 번의 화재 때문에 법당 내에 설치하게 된 것이라고 한다. ${ }^{80)}$

이는 『신편겸창지』 ${ }^{871}$ 의 「건장사」조의 "불전 내, 토지당에는 태 제, 태원, 위태천, 감응사자, 성덕태자, 천수관음, 문수, 약사의 상이 있 음" ${ }^{88)}$ 이라는 기록과, 『신편상모국풍토기고』「건장사」조의 “전내 토지당 중앙에 태상군, 왼쪽에 장부판관, 오른쪽에 감응사자를 안치 함" ${ }^{99)}$ 이라고 한 기록을 통하여 확인할 수 있다.

한편, 한국 불교에서는 가람각이라는 전각명을 사용하며, 그 외에 국

84) 『勅修百丈清規』권3( 『대정장』48, p. 1125중) 「入院」挂搭已到佛殿 拈香次土地堂祖堂炷香

85) 『䡃修百丈清規』 권5( 대정장』48, p.1136하)「沙彌得度」自行堂鳴鈸引剃頭人出土地堂祖堂佛 殿炷香禮三拜

86）田中知佐子「建長寺伽藍神像をめぐる一考察」」『仏教芸術』301, pp.82-83

87) 新編鎌倉志』는 정향2년 (1685)에 河井恒久友水편찬하였다. 총8권으로 구성되어 있다.

88)『新編鎌倉志』권3「建長寺」(http://dl.ndl.go.jp/info:ndljp/pid/2563543(일본국립국회도서관 디 지털 컬렉션)참조) “佛殿) 土地堂二八 太帝 太元 韋駄天 感應使者聖德太子 千手觀音 文殊 藥師, 像アリ”

89) 『新編相模国風土記稿』제4집 「鎌倉郡」(http://dl.ndl.go.jp/info:ndljp/pid/763970(일본국립국 회도서관 디지털 컬렉션)～“佛殿內土地堂 中央二太常元 左二掌簿判官 右二感應使者 安ス” 
사단, 성황각 등이 가람각의 역할을 하고 있다. 통도사와 표충사의 가 람각, 해인사의 국사단, 월정사의 성황각이 그것이다.

그런데, 한국은 경전에도 출전이 없는 '가람각'을 사용하는 이유가 무 엇인가. 한국민속에서 가람신의 역할에 해당하는 신으로 성황신앙이 있다. ${ }^{90)}$ 성황을 모신 곳을 성황당이라고 하는데, 중국과 일본에서 사용 하는 '가람당'을 사용하게 되면, 성황당과 동격이 되는 것이다. 때문에

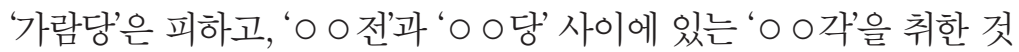
이라고 사료된다. ${ }^{91)}$

90) 쿠보노리타다(萑德忠)는 동아시아 불교국의 성황신에 대하여 대만에서는 지역의 음양 양계의 지배신의 성격, 홍콩에는 마을촌자에 해당하는 토지공公으로, 잃어버린 물건 등을 찾아주는 신 의 의미가 있으며, 한국은 고려시대에 전래된 중국의 성황신앙과 관련성을 지니며, 명계를 지배 하는 관념은 없으며, 단순히 마을의 수호신의 역할을 하고 있다고 한다. (䧱徳忠「東アジアの土 地神信仰」『宗敉研究』46-3, p.114) 하지만, 고려시대 순천과 순창의 성황신앙은 특정 인물을 인격신화하여 명계와의 연관성도 지니고 있다. (노동명「고려시기 순천의 산신 · 성황신앙」 역사학보』174, 2002년 ; 김갑동「고려시대 순창의 지방세력과 성황신앙」『한국사연구』97, 1997년) 한국의 성황신앙은 매우 다양한 성격을 지니며, 이에 대해서는 민속학에서 상당한 연구 성과가 있으므로, 본고에서는 생략하고자 한다.

91) 불교전각명에 있어서‘ㅇ 전'은 불보살을 모시는 곳이며, ‘ㅇ 악’은 중단의 호법선신, 나한등을 모시는 곳이며, '이당'은 조사스님들을 모시는 곳이다. ' 0 인은 의식 등을 행하거나 관람하 기 위하여 훍이나 돌을 쌓아서 주변보다 높게 만든 곳이다. (대한불교진흥원 『월정사』,pp.110111) 


\section{2) 한국 가람각의 역사와 현황 22}

\section{(1) 통도사 가람각}

통도사는 경내를 상노전, 중노전, 하노전으로 구분하고 있는 독특한 가 람구조를 갖고 있다. 가람각은 영산전, 극락보전과 함께 하노전에 있 는 천왕문의 남동쪽에 자리하며, 천왕문과 연결된 담장왼편 공간에 있 는 4 면 단칸의 작은 전각이다.

전각에는 '가람각'이라는 현판이 걸려있으며, 내부에는 가람탱화와 가람패가 봉안되어 있다.

가람각의 창건 기록은 알 수 없지만, 「통도사제성전열목」 에 '석가 여래두골사리가사봉안계단'을 필두로 전각들이 기록되어 있는데, 그 중에 '가람전'이라는 전각명이 명기되어 있다. ${ }^{93)}$ 이 기록이 통도사 가람 각에 관한 가장 오래된 기록이다.「통도사제성전열목」은 필사본으 로 『통도사사적략록』 ${ }^{94)}$ 에 수록되어 있다.

그런데, 「통도사제성전열목」 말미에 ‘계미년 오월 이십육일 주지 가 적다.95)라는 기록이 있다. 즉, 「통도사제성전열목」은 '계미'년에 작성된 문헌인 것이다. 그렇다면, 『통도사사적략록』의 성립연대, 즉

92) 한국의 가람각은 논자가 2014년 11월 14일부터 11월 15일까지 해인사, 표충사, 통도사의 순서로 현지답사를 통하여 사진촬영과 여러 스님들과의 대담을 통하여 정리한 부분이다.

93) 通度寺諸聖殿列目」“伽藍殿（『通度寺誌』, p.63)

94)『통도사사적략록』은「통도사사리가사사적략록」을 비롯하여 8가지의 사료를 모아 놓은 사료 이다. 이 사료들의 간기를 참고로 성립연대를 고찰하고 있다. "천순4년(1460)에 그간 몇 가지로 전해오던 것을 기록했다가 만력8년(1580)에 다시 쓰고, 만력37년(1609)에 학명스님이 필사하여 본사에 보관하였다고 본다. 이후 숭덕7년(1642)에 퇴은경일에 의하여 개간되었다.” (『通度寺 誌』, 「해제」V쪽)

95)「通度寺諸聖殿列目」 ‘癸未五月念六日記佳持”( 『通度寺誌』, p. 67) 
1460 1642년 사이에 있는 계미년은 천순 7년(1463), 가정 2년(1523), 만 력 11년(1583)에 해당한다. 하지만, 이 3시기의 간기 가운데 어느 시기 에 해당하는 것인지 이 기록만으로는 규정하기 어렵다. 다만, 가람각 이 15 세기 중반에서 16 세기 후반에는 통도사 경내에 존재하고 있었던 것은 확인할 수 있다.

한편, 1905년 동경대학교에 서 한국의 건축에 대하여 조사 한 보고서 『한국의 건축과 예 술』에〈도1〉의 통도사 평면도 가 수록되어 있다. ${ }^{96)}$ 천왕문 옆 의 명칭이 기입되지 않은 작은 전각이 보이는데, 가람각으로 추정된다.

그런데, 1912년 9월30일에 인

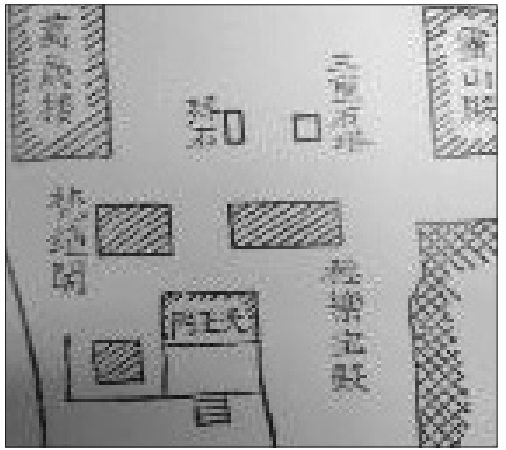

〈도1〉 통도사 평면도

가한 통도사 본말사법의 '사격'에는 '가람단' ${ }^{97)}$ 이라고 기재되어있다.

그렇다면, 『한국의 건축과 예술』 의 평면도에 있는 전각명이 '가람 각'이었는지, 아니면 '가람단'이었는지 단정하기가 어렵다.

정리를 하면, 통도사 가람각의 전각명은, 가람전에서 가람단, 그리고 가람각으로 변화되어 왔음을 알 수 있다. 이와 같은 변화는 단순한 전 각명의 변화가 아니라, 가람각의 위격이 상단에서 중단으로 하향된 것 이라고 할 수 있다.

96) 東京帝国大学工科大学『韓国の建築と芸術』建築文化, 1905년, 〈제273圖 통도사 평면도〉(韓国 の建築と芸術刊行会『韓国の建築と芸術』1988년 복간본 참조)

97) '珈藍壇' (동국대학교 불교문화연구원 『조선불교통사』권2, p.663. 「경상남도 양산군 영축산 통 도사」조) 
한편, 몇 년 전 통도사를 참배하였을 때는 가람각에 가람신상이 모 셔져 있었는데, 신상이 보이지 않았다. 대신 그 자리에 가람패가 놓여 있었다. 박물관에 문의하자 통도사 박물관에 근무하셨던 신용철(현 양 산시립박물관 관장) 선생님을 소개받아서 상세한 설명을 듣게 되었다. 신관장님의 설명을 요약 정리하였다. ${ }^{98)}$

현재의 가람각은 1988 년에 원명스님(현 통도사 방장큰스님)께서 주지소임을 보실 때 개축하였습니다.9) 가람탱화도 이 당시에 함께 조성하여 봉안하였다고 합 니다. 가람각에 있던 불상은 1990 년대 초에 일본의 한 단체에서 통도사를 방문하 였을 때, 방장 월하큰스님께 선물하였는데, 큰스님께서는 마침 가람각에 불상도 봉안되어 있지 않고 해서 가람각에 모시게 되었습니다. 그러나, 일부에서는 일본 의 신상을 불보종찰에 모시는 것이 격에 맞지 않는다는 지적도 하였지 만, 큰스 님께서 봉안하셨기 때문에 그대로 두었습니다. 그러다가, 정우스님께서 주지소임 을 마치실 무렵인 2010년에 신상은 박물관 유물실로 옮겨지게 되었습니다. 신상 이 있던 자리에는 원래 가람패가 있었는데, 다시 가람패를 봉안하여 옛 모습을 갖 추게 되었습니다.

가람각에 모셨던 〈도2〉의 신상은 전체적으로 검은 색을 띠고 있으 며, 크기는 상하 $53 \mathrm{~cm}$, 좌우 $28.4 \mathrm{~cm}$, 측면두께 $25.2 \mathrm{~cm}$ 이다. 양손은 가 슴 높이로 올려 각기 지물을 들고 있으며, 두 발은 쌀가마 같은 것을 밟 고 있다. 이 신상은 일본 칠복신의 하나인 대흑천상이기 때문에 원래, 가람각에 모실 수 없었던 것이다.

98) 2014년 11월 11일 신용철 관장님과의 통화내용이며, 관장님의 허락을 얻어 본고에 수록하였다.

99) 신관장님은 개축 이전의 가람각 사진이 마이크로 필름 형태로 유물관에 보관되어 있다고 한다. 이에 대해서는 논자가 확인하지 못하였는데, 향후 진행하고자 한다. 


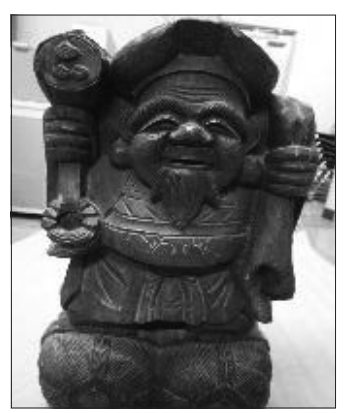

가람각 신상 통도사 박물관 제공

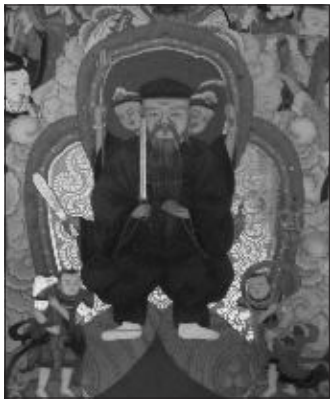

가람각 탱화 가람신상

〈도1〉 가람각 신상

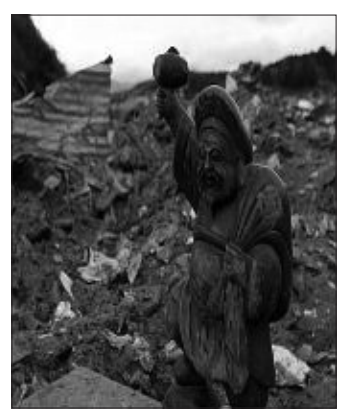

일본 대흑천상

http://imagesearch,naver.com

한편, 중국의 토지당에 모셨던 가람신상은 일본으로 전래되었다. 일 본 최고最古의 가람신은 건장사의 가람신상으로 장대제, 대권수리, 장 부판관, 감응사자, 초보칠랑의 5 구이다. ${ }^{100)}$

오통신과 관련성이 깊으며, 불의 신인 화광대제華光大帝와 초보칠 랑은 우지宇治 황벽산의 만복사에 전하며,101) 교토의 동복사에는 장 부판관과 감응사자에 상응한다고 보여지는 가람신상이 현존한다. ${ }^{102}$

간단히 살펴보았지만, 중국과 일본의 가람신상은 뱀의 형상인 마후 라가왕 가람신이 아님은 분명하다. 가람 18 신의 형상에 대한 기록이 없 어 확인할 수는 없지만, 그 중의 일부가 전승된 것이 아닐까 추측할 뿐

100）中世古祥道「招宝七郎大権修理菩薩について」『宗学研究』35, p.233

張大帝, 大權修理, 掌簿判官, 感應使者, 招寶七郎에 대한 연구는 田中知佐子「建長寺伽藍神像 をめぐる一考察」(『仏教芸術』301, 2008년)이 참고가 된다. 건장사 5 구의 가람신상은 건장5 년(1253), 혹은 영인원년(1293)에 조성되었다고 추정하며, 2010년에 중요문화재로 지정되었다.

101）二階堂善弘「民間信仰に扔ける神形象の変化について」『東アジア文化交渉研究』1,p.180

102）田中知佐子「建長寺伽藍神像をめぐる一考察」『仏教芸術』301, p.79

또한, 동복사에는 위태천상이 있는데, 이는 2007년 「足利義滿六白年御忌記念 京都五山 禪の 文化」 전시회에 가람신의 명칭으로 출품되었다. 
이다.

한편, 통도사 가람각에는 가람탱화가 봉안되어 있다. 가람탱화는 상 단, 중단, 하단의 삼단으로 구성되어 있으며, 상단의 주불인 제석천 ${ }^{103)}$ 바로 아래에 전신이 검은 색을 띤 가람신이 그려져 있다. 오른 손에는 칼날을 위로 세워서 쥐고 있으며, 왼손에는 복숭아를 갖고 있다. 두광 과 신광이 있으며, 두광 안에는 좌우로 두 명의 협시보살이 있다. 특 히, 두발로 쌀가마를 밟고 서 있는 것이 박물관으로 이전된 신상과 너 무도 흡사하다.

이 가람탱화와 이전된 신상의 관계를 증명할 수 있는 것이 가람탱화 의 조성연대이다. 시주질에 '불기 2535년’이라고 명기된 연도는 1991년 으로 신상이 통도사에 유입된 시기와 일치한다. ${ }^{104)}$ 가람탱화에 묘사된 가람신 역시 대흑천상인 것이다. 그렇다면, 가람탱화에 대한 봉안 여부 도 사중에서 신중하게 고려해야할 문제라고 판단된다.

결론적으로, 원래 통도사 가람각에는 가람탱화도 가람상도 없었으 며, 가람패만이 있었던 것을 쉽게 추측할 수 있다. 가람패는 정확한 기 록은 없지만, 통도사에 남아있는 다른 목패들과 비슷한 화려한 조각기 법으로 미루어 18 세기의 불구로 추정된다. 옛 자료에 의하면 바깥벽 에 붉은 색으로 말을 그린 그림이 있었다고 하나, 지금은 남아있지 않 다. ${ }^{105)}$

한편, 경전에 가람신의 공양과 관련한 훙미로운 내용이 전한다.

103) 이 제석신은 통도사 대광명전과 해인사 길상암 신중탱화의 제석천의 모습과 흡사하다.

104 ) 1988 년 가람각 개축과 함께 가람탱화를 조성하였다는 신관장님의 기억은 정확하지 않은 것 이다.

105) 통도사 발행 『월간 보궁』 384, p.27 
호가람신의 사당에 매일 대중이남은 밥을두면 까마귀가 물어갔다. 습득이지팡이 를두드리며말하기를, 너는 밥도지키지 못하면서 어찌 가람을보호한다고 하느냐. ${ }^{109}$

당나라 때에는 가람신에게 대중이 공양을 할 때 조금씩 헌식한 것 을 모아서 공양하였으며, 별도로 공양을 마련하지 않았음을 알 수 있 다. 이는 가람신을 승보보다 하위에 두었다는 의미이다. 즉, 가람수호 신이지만, 신중이나 사천왕들이 갖는 옹호성중과 동등한 위격을 지니 고 있지 않다.

현재, 통도사 가람각의 예불의식이나 공양은 불공이 있을 때만 행하 여진다. 또한 가람각은 위치적으로도 잘 보이지 않고, 가람각의 성격 을 잘 모르기 때문에 일반인들이 참배하는 것은 드물고, 주로 무속인들 이 적극적으로 참배한다고 한다.

\section{(2) 표충사 가람각}

밀양 재약산에 위치하고 있는 표충사의 가람각도 통도사와 마찬가지 로 '가람각'이라고 칭한다. 표충사는 통도사의 말사이므로, 양사兩寺는 가람각이라는 전각명을 공유하고 있는 것이다. 그런데, 표충사에는 두 개의 가람각이 있는데, 구가람각 - 신가람각, 또는 외가람각 · 내가람 각이라고 한다. ${ }^{107)}$

우선, 구가람각은 외가람각이라고 하는데, 표충사 가람 밖에 위치하

\footnotetext{
106)『景德傳燈錄』권27(『대정장』51,433c)

有護伽藍种廟 每日僧厨下食為烏所有拾得以杖抶之日 汝食不能護 安能護伽藍乎

107 ) 표충사 가람각에 대해서는 2014년 11월 15일에 성관스님(현 표충사 총무)께 조언을 구하였다.

스님의 허락을 얻어 인용 수록하였다.
} 
고 있기 때문이다. 전각은 지면에서 조금 떨어져 있으며, 편액은 걸려 있지 않다. 사람이 들어갈 수 없을 정도로 협소한 내부에는 불단도 없 이 다기, 향로와 촛대가 바닥에 놓여져 있다. 신상도 탱화도 없으며, 한 지에 “奉請苾夠伽藍神位”라고 쓴 가람패가 벽에 붙여져 있다. “필추'는 ‘비구라 의미이다. 예전에 외가람각 뒤편에 커다란 고목나무가 있었는 데 사람들은 이 나무를 신위神位로 여겼는데, 저절로 고사를 하자, 그 후에 누군가가 이 내용을 한지에 써서 붙였다고 한다.

한편, 내가람각은 수충루를 지나 경내로 들어오면, 수충루의 왼쪽에 위치하고 있다. 나무판에 붓글씨로 '가람각'이라고 쓴 편액이 걸려있 다. 내부는 이단으로 된 불단이 있으며, 불단위에 가람패와 함께 다기, 향로, 촛대가 있다. 가람패에는 “南無伽藍守護神位”라고 쓰여져 있다. 외가람각과 마찬가지로 신상과 탱화가 없다.

내가람각은 목산 지은 스님(현, 울산 백양사 주지)이 주지소임을 보 시던 1980년대 후반에 건립하였다. 내가람각을 지으면서 자연히 내 · 외가람각으로 불리워지게 된 것이다.

가람각에서 일상예불을 하지는 않는다. 다만, 내가람각은 향사훙ㄹㄹ ${ }^{108)}$ 때 공양을 올리고 간단히 의식을 갖으며, 외가람각은 정초, 초파일, 동지 때에 과일 등의 공양물을 올리며, 평소에는 마을사람들이 소원이 있거나 하면 와서 공양올리고 기도를 한다. 예전에는 현 박물관이 들 어선 장소가 밭이었는데, 그곳에서 공양을 올리고 기도를 한 후, 외가 람각에 기도하였다고 한다. ${ }^{109)}$

108) 향사는 사명대사를 기리는 유· 불식의 추모제로, 일 년에 두 번 3월과 9월의 ‘초정일初丁 日'에 갖는다.

109) 일부에서는 외가람각을 영가각이라고 칭하기도 한다. 송광사의 천추각이나 세월각과 같은 성 격을 지녔다는 것이다. 그러나, 성관스님께서는 이는 오해라고 지적하셨다. 


\section{(3) 해인사 국사단}

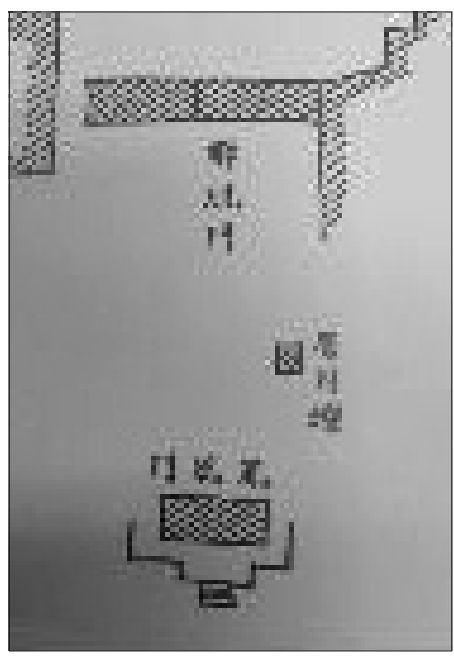

〈도3〉 해인사 평면도

해인사의 가람각은 '국사단'이라고 칭한다. 봉황문과 해탈문 사이에 위치하고 있으며, 봉황문을 지나서 오른편에 위치한 6평의 작은 전각 이다. 단을 만들어 석축을 쌓고 그 위에 건물을 지었다. 4 개의 돌계단 이 설치되어 있다. 정면에는 '국사 단’이란 편액이 좌측에는 ‘指公曾點 地'라는 현판이 걸려 있다. '지공증 점지'는 '지공이 점지한 곳'이라는 뜻이다.

국사단 역시 『한국의 건축과 예 술』 에서 〈도3〉의 해인사 평면도 ${ }^{110)}$ 를 통하여 확인할 수 있는데, 현재 의 자리에 위치하고 있으며, 통도사와는 달리 전각명이 명시되어 있다. 국사단의 연역은 『가야산해인사지』를 통하여 알 수 있다.

본대의 초창연대는 알 수 없고, 1817년 화재시에 이 건물은 화마가 미치지 아니 하였으며, 1899년에 범운대사가 중수하고, 1967년 박영암주지화상이 보수하고 탁자위에 토조로 된 말, 토끼, 돼지, 개구리 등 많은 토우를 치워버리고 국사대신의 신위만 안치하였다. 현 건물은 1805년에 세웠다. ${ }^{111)}$

110) 東京帝国大学工科大学『韓国の建築と芸術』建築文化, 1905년, 〈제274圖 해인사평면도〉

111) 이지관 『가야산해인지』,p.193 
19세기 초에 세워진 후, 화재에도 소실되지 않고 두 번의 중수와 보 수를 거쳐서 현존하고 있다.

한편, 탁자에 동물의 토우가 놓여있었다고 전하는데, 이와 같은 현 상은 일본사원에서도 볼 수 있다. 일본의 선종문헌인 『열조제강록』 ${ }^{112)}$ 에 "능인원선사가 처음 복엄사에 주할 때, 가람당에 들어가 토우가 매 우 많은 것을 보고, 불식간에 실소하였다." ${ }^{113)}$ 는 기록이 있다. 토우를 본 스님이 그만 실소하였다는 것은 불교적이지 않음을 대변하는 것이 다. 원래, 토우는 주술적 신앙표현이나, 무덤의 껴묻기용품으로 사용 되었기 때문이다.

시대적 차이는 있지만, 가람각 토우라는 양국의 동일한 문화적 현상 에 대한 해석은, 가람각에 내포된 비불교적이고 주술적인 민속신앙과 의 습합이 표출된 것이라고 본다. 하지만, 전각명을 비롯하여가람신상 봉안의 유무 등, 뚜렷한 문화적 차이를 갖는 양국의 가람각 토우의 현 상을 단순히, 주술적이고 민속학적이라는 해석차원에 머물러서는 안 된다고 사료된다. 향후 이에 대한 심도있는 연구가 이루어지기를 바라 며, 본고에서의 상세한 고찰은 생략하고자 한다.

한편, 국사단 앞에 설치되어 있는 안내문에는 다음과같이 적혀 있다.

국사단은 국사대신을 모신 단으로서, 국사대신은 도량이 위치한 산국을 관장 하는 산신과 토지가람신을 가리킨다. 가야산신인 정견모주는 하늘의 신 아비가와

112)『列祖提綱錄』은 呆穿行悦(1618-1684)이 편찬하여, 강희5년(1666)에 완성하였다. 모든 종류의 선종사서 및 어록에서 역대조사들의 상당법어 3 천여 개를 골라서, 『칙수청규』 에서 정한 연중 행사의 순서로 분류하고 편집하였다.

113）『列祖提綱錄』권22「伽藍堂烓香法語」(『만자속장경』64,p.178상) 能仁元禪師初住福嚴入伽藍堂見土偶甚夥不覺失笑 
의 사이에 두 아들을 두었다. (중략) 가람을 수호하는 신을 모셨기 때문에 도량 입 구에 배치되어 있다.

현재, 국사단 내부에는 정견모주 탱화만 한 점 있으며, 신상이나 목 패는 놓여 있지 않다. 그런데, 『가야산해인사지』 에서는 국사대신 신 위의 존재만 확인될 뿐 탱화나 신상에 대한 언급은 없다. 그렇다면, 안 내문에 의문이 생긴다. 국사대신은 산신과 토지가람신을 관장하는데, 해인사 산신인 정견모주를 모시고 있는 것이다.

이와 같은 제반에 걸친 변화의 양상이 때로는 문헌이 아닌 구전을 통 하여 확인되기도 한다. 종묵 스님(현 해인사 승가대 교수사)의 국사단 에 대한 설명을 요약하였다.

현재의 국사단 자리는 원래 마을사람들의 성황당이 있었을 것이라고 본다. 국 사단 옆의 커다란 느티나무가 그것을 증명한다. 1963년에 종성스님(현 홍제암 감 원)이 처음 오셨을 때, 국사단에는 십이지신의 목패가 놓여있었다고 한다. 그 후에 는 국사대신을 모셨고, 근래에 어느 사학자가 국사단은 산신각인데, 해인사 산신 인 정견모주를 모셔야 한다고 한 것을 듣고, 2007년에 국사대신탱화를 박물관으 로 옮기고 지금의 정견모주 탱화를 봉안한 것이다. 국사단에 신상을 봉안한 적은 없다. 1960년대에 대처승과 대립하여 소송을 할 때에 영암스님께서 직접 마지를 지어서 올리고 국사단에서 기도를 하고는 한 번도 소송에서 진 적이 없다. 국사단 의 기도는 원래는 1 월 15 일에 해인사 대중전체가 기도를 하였는데, 일제강점기 말 기에 없어진 것 같다. 특히, 종성스님께서는 1973년부터 현재까지 매달 그믐에 국 사단에서 기도를 하시는데, 한 번도 거르신 적이 없다. 그믐날 술시나 해시에 기 도를 하는데, 이 시각이 국사대신의 공양시간이기 때문이다. 술, 당근, 묵, 떡, 삼색 과일, 삼색나물, 공양을 준비하시고, "나무국사대신" 을 30 분 정도 염불하시고, 
기도 후에 저녁공양을 드신다. 한편, 지금도 마을사람들은 초하루날 사적인 소원 이 있으면 기도를 하는데, 주로 산신기도를 하는 사람들이 많으며, 오징어와 술, 시 루떡 등을 올린다.

위의 내용에서 다양한 사실을 알 수 있다.

첫째, 『가야산해인사지』에서 말한 ‘국사대신 신위’가 목패였다는 점이다. ${ }^{114)}$ 둘째, 이전에는 국사대신도가 봉안되어 있었다. 셋째, 홍제 암 감원스님께서 40 여년이 넘도록 매달 국사단 기도를 하고 있다. 넷 째, 국사기도는 매월 그믐날 술시나 해시에 하며, 공양물로 술, 당근, 묵, 떡, 삼색과일, 삼색나물을 올리고, "나무 국사대신"을 염불한다. ${ }^{115)}$

현재의 정견모주를 봉안하기 이전에 모셨던 〈도4〉 국사대신도는 박 물관 수장고에 보관중이다. 화폭은 가로 $60 \mathrm{~cm}$, 세로 $78.5 \mathrm{~cm}$ 이며, 대신 도는 높이 $49 \mathrm{~cm}$, 폭 $23 \mathrm{~cm}$ 이다. 머리와 턱수염이 더부룩하며, 부리부리 한 눈과 코는 달마도를 연상시킨다. 붉은 빛의 긴 옷을 걸치고 있는데, 가슴부분에 노란 대를 두르고 있다. 오른손으로 오른쪽 옷자락을 잡아 올려 오른쪽 다리를 드러내고, 왼손은 허리에 살짝 대고 있다. 종아리 까지 올라오는 검은 색 신발을 신고 양발을 살짝 벌리고 서 있다. 권속

114 ) 그런데, 몇 가지 의문점이 남는다. 『가야산해인지』의 기록만으로 본다면, 1992 년까지 국사단 내부에는 목패만 있었다고 생각된다. 그러나, 『가야산해인지』보다 2년후에 발간된 이상해 『해인사건축도집』 에는 “지금은 국사대신의 초상화 신위만 안치하고 있다."(p.58)고 한다. 물 론, 초상화를 “신위'라고 잘못된 인식을 하고 있지만 『해인사건축도집』의 기록이 옳다면, 가 야산해인지』를 발간할 때, 현장답사 없이, 문헌기록에 의해서만 출판한 것이다. 그렇지만, 편 집자인 지관스님의 본사가 해인사인 점을 고려하다면, 국사단에 봉안된 것이 목패인지, 탱화인 지는 인식하고 있었을 것이다. 이 점 또한 납득되지 않는다.

115) 공양물 중에 당근은 말의 기호식품인데, 통도사 가람각 벽화에 있었다고 하는 말그림이 상기된 다. 연관성을 지니는 것인가 


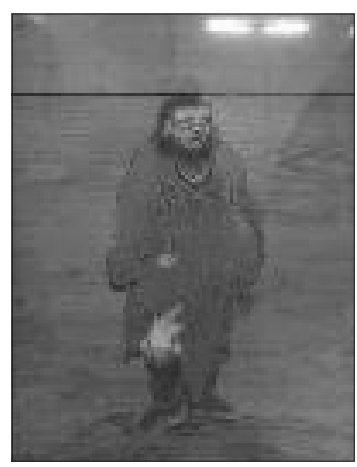

〈도3〉 국사대신도

이 없는 독존의 형식이다.

국사대신 명칭의 유래를 알 수 있는 기 록은 없지만, 『석씨요람』 에 “사원의 벽 에 대신의 그림이 있는 것이 바로 이 (가 람)신이다." ${ }^{111}$ 라는 내용을 근거로 할 수는 있다. 그렇다면, 『석씨요람』은 무엇을 근거로 대신이라고 칭한 것일까.

민간신앙의 대상인 성황신이나 산신 등 에 대한 봉작封䨖은 당 · 송시대에 시작되 었다. 여말선초에도 성황신에게 公 - 候 · 伯 등의 작호를 사한 사례가 있으며, 대왕이라는 호칭까지 내려주었다. ${ }^{117)}$ 송대에 저술된 『석씨요 람』 에서 지칭한 '대신'이란 이와 같은 시대적 배경을 지니고 있는 것 이다.

한편, 국사대신은 어떠한 성격을 지니는 것인가?

『가야산해인사지』에 국사단 편액의 의미를, "국사단은 한국사찰 에서만 볼 수 있는 특유한 수호신의 일종이다. 국사대신은 산신 중의 차산국내항주대성산왕대신과 신중 중에 하계당처 토지가람신 등을 가 리킴이니, 해당 사찰의 결계도량만을 국한하여 사호하는 영기 등을 말 한다." ${ }^{118)}$ 고 설명하고 있다.

즉, 국사대신은 사찰의 결계도량만을 국한하여 수호하는 산신과 신 중의 성격을 겸하고 있는 것이다. ${ }^{119)}$ 이와 같은 중층의 성격은 건축공

116)『釋氏要覽』권상 (『대정장』54,p.263하) 凡寺壁有畫大神者即是此神也

117) 김갑동「고려시대의 성황신앙과 지방통지」『한국사연구』74, pp.20-21

118 ) 이지관 『가야산해인지』, p.193.

119) 이상해는 “국사란, 국局을 관장한다는 뜻으로, 토지신과 상통하며, 토템이즘의 신장 같은 역할 도 한다." (이상해『해인사건축도집』, p.58)고 하여, 토지신의 의미로 해석하고 있다. 
간적인 면에서도 “국사단은 중요한 건물이다. 그러나 중요하지 않은 건 물이기도 하다. 봉황문과 해탈문 사이의 이 공간은 국사단의 이중적 성 격을 대변하듯 지형적으로 교리적으로 이중적인 경계의 공간이다." ${ }^{120)}$ 라고 하여 확인되고 있다.

국사대신이 산신과 토지가람신의 성격을 겸하고 있는 것은 불교신 앙적인 면이나, 불교민속학적인 면에 있어서도 매우 특이한 점이다. 국 사대신의 성격을 이와 같이 정확하게 인식한다면, 해인사 산신인 정견 모주를 국산단에 모시는 것은 부적합한 일인 것이다.

결론적으로 국사단의 위격은 성황신앙에서 사찰의 산신 - 토지가람 신으로 그리고 가야산산신으로 변화되어왔음을 알 수 있다.

한편, 『조선불교통사』 하권 「범어일방임제종지」 조에 국사단과 강대련 스님 ${ }^{121)}$ 과의 흥미로운 기록이 있다.

장경을 인쇄하여 빠진 책을 보충하고, 내전에서 큰 시주를 내리자, 전답을 사서 해인사에 기부하였다. 인경하고 남은 재화로 전답을 사서 해인사 국사단에기부하 였는데, 매년 쌀 1백두를 거두었다. ${ }^{122)}$

위의 기록은 근대 국사단의 위상을 평가할 수 있는 중요한 자료이 다. 국사단에 기부한 전답은 삼국시대부터 시작된 위전位田인 것이다. 신라의 문무왕이 수로왕묘에 왕위전을 바쳤고, 고려 우왕 14년 (1388)에는 조준이 토지개혁을 할 때, 성황 등에 위전을 지급할 것을 주

120) 이기선「가람각」『불교』 $672, \mathrm{p} .45$. 건축사가인 김봉열의 설을 재인용함.

121) 姜大蓮(1875-1942) 본관은 진주이며, 법호는 금허, 대련, 송거이며, 스스로 명고산인ㅁ⿹\zh4灬鼓山人이 라 호칭하였다. 금강산 장안사 진허스님에게 출가하였다.

122）印經以補充關書 內下大施 買田以寄附海印 以印經之餘財買田 以寄附海印寺局司壇 歲收百斗 米 (동국대학교 불교문화연구원 『조선불교통사』 권6, pp.399-340 
장하였으며, 조선 세종대에는 위전, 태종대에는 녹미춦분가 성황당에 위전으로 지급되었다. ${ }^{123)}$ 성황당 위전은 특히 당을 관리하는 자에게 지 급한 토지인 것이다.

일제강점기의 국사단 위전은 대장경 인경과 관련한 국사단의 역할 을 고찰해야하는 문제이다. 지금은 해인사 입구에 있는 산중 안내판에 도 국사단이 누락되어 있지만, 일제강점기에는 국사단이 가람수호 이 외에 또 다른 의미와 역할을 하고 있었음을 추측할 수 있기 때문이다. 이와 같은 사실만으로도 국사단의 중요성은 간과할 수 없는 것이다. 근 래에 사중에서 국사단을 이전할 계획을 가졌으나, 문화재청에서 금지 시켰다고 한다.

현재, 평소의 국사단 예불은 없으며, 정월 초하루에 간단히 삼배를 올리는 정도이다.

\section{3) 한국 가람각의 한국민속적 요소와 의미}

한국 가람각의 한국민속적 요소와 의미는 무엇인가. 달리 말하면, 한국 가람각의 불교민속적 요소와 의미가 될 것이다. 이에 대해서는 몇 가지 항목으로 나누어서 서술하고자 한다.

첫째, 가람패 봉안의 문제이다.

불교전각에 불보살상과 탱화를 봉안하는 것은 불교의 문화적 전통 이다. 그러나, 한국 가람각에는 가람신상도, 가람탱화도 모시지 않았 던 것이 전통이었음을 고찰을 통하여 충분히 알 수 있었다. 공통적으 로 목조 가람패를 모셨던, 문화적 현상을 파악하기 위해서 시대적 배

123) 김갑동「고려시대의 성황신앙과 지방통지」『한국사연구』 74, p. 21 
경을 살펴보았다.

태조시대에 마련된 조선시대 성황신앙에 대한 제도화 중에 "신상을 폐지하고 목제 위패를 놓고 제사지낸다. 유학자, 특히 주자학자들은 신 상을 부정하고 우상으로 간주한다." ${ }^{124)}$ 는 내용이 있다. 한국 가람각의 창건 시기는 알 수 없지만, 가람각 관련 문헌기록이 대부분 조선시대임 을 감안하면, 위의 같은 시대적 배경을 무시할 수 없었을 것이다. 때문 에 가람각에는 전통적으로 가람패만을 모시게 된 것이며, 이는 가람각 과 성황당이 ‘수호'라는 동일한 성격을 갖는데서 연유한 것이다.

둘째, 가람신상의 부재에 대한 견해이다.

가람신상의 부재를 건궁성주와의 관계성으로 고찰하였다.

한국 가신신앙에서 주요 가신은 대부분은 신체神體를 갖는다. 신체 는 신을 상징하는 것으로, 가택신의 경우, 쌀을 담은 항아리를 가리킨 다. 그러나, 우물신, 마당신, 측신 등은 신체를 갖지 않는데 이를 건궁 성주라고 한다. 건궁성주라 할지라도 성주에 대한 신관념은 뚜렷하다. 애초부터 신체가 없이 섬기는 가신은 다른 주요 가신에 비해 상대적으 로 약화되어가지만 그 집안의 생업과 직결될 경우에는 전승력을 발휘 한다. ${ }^{125)}$

가람신은 건궁성주처럼 수호신이지만 신중 등의 옹호성중에 비하여 신격이 낮다. 『경덕전등록』 에도 가람신에게는 별도의 공양을 마련 하지 않고, 대중이 남은 밥을 모아서 공양하였다고 한다. 이는 가람신 을 승보보다 하위에 두었다는 의미이며, 신중이나 사천왕과 동등한 위 격을 갖지 못했다는 의미이다.

124) 서영대「한국과 일본의 성황신앙 비교」『중국사연구』 12, p. 202

125) 김명자 외 『민속문화, 무엇이 어떻게 변하는가』, pp. 218-220 
그러나, 가람신상을 모시지 않았다고 해서, 가람신이 부정되는 것은 아니며, 가람각 기능이 상실되는 것도 아니다. 최근 통도사의 경우처럼 신자들이 불공을 요청할 때는 기도전각으로서의 기능을 갖는다. 이와 같은 성격이 건궁성주와 너무도 흡사하다. 칠성신앙 역시 상像이 없는 것은 이와 같은 영향이라고 본다.

가람신상의 부재를 건궁성주와 연결하여 고찰한 것은 다소 무리가 없지 않다. 그러나, 터주신과 가람신, 터주신과 칠성신앙, 터주신과 사 신蛇神의 관계를 규명할 수 있다면 이는 매우 중요한 논점이라고 생 각한다.

셋째, 국사대신의 호칭이다.

해인사의 국사대신이라는 호칭이 언제부터 사용되었는지 알 수는 없지만, 『석씨요람』 의 ‘대신'이라는 기록을 인용하여 간단히 사회적 배경도 살펴보았다.

당 · 송시대에 시작된 성황신이나 산신 등에 대한 봉작封爵은 여말 선초에도 사례가 있었다. 성황신에게 公·候 - 伯 등의 작호를 사하였 으며, 심지어는 대왕이라는 호칭까지 내리기도 하였다. 가람각과 성황 신과의 밀접한 관련성을 고려하면, '대신'은 이와 같은 배경에서 붙여 졌을 가능성이 높다.

넷째, 가람각 주변 고목나무와 토우의 관련성이다.

한국 성황당의 대표적 상징의 하나가 신목神木이다. 그런데, 표충사 와 해인사의 가람각 바로 옆에 고목나무가 있는 것은 간과할 수 없는 점이다. 문헌기록은 없지만, 스님들의 말씀처럼 가람각 자리에 성황신 앙이 선행하였을 가능성은 충분하며, 가람각 주변의 고목나무가 신목 일 가능성 또한 매우 높다.

한편, 토우는 주술적 신앙표현이나, 무덤의 껴묻기용품으로 사용되 
었다. 그런데 해인사 가람각에는 동물 형사의 토우가 단위에 놓여있었 다고 한다. 이 토우야말로 가람각의 불교민속적인 요소를 가장 잘 표 현하고 있다고 보여진다.

다섯째, 가람각 주요 참배자와 공양물, 기도시간에 관련한 것이다.

한국 가람각의 주요 참배자는 대부분 무속인이다. 이는 가람각이 산 신각, 칠성각, 토지신, 성황신 등 다양한 성격을 내포하고 있기 때문이 다. 『석씨요람』에서도 살펴보았듯이 가람신은 현보를 초래하는 신 격을 갖기 때문에 소원이 빠르게 이루어진다고 하는 믿음도 갖고 있 다. 경내의 한쪽에 치우쳐 있는 위치와 익숙하지 않은 전각명으로 인 하여 일반인들이 쉽게 참배하지 않으며, 실은, 스님들에게도 생소한 전 각이다.

가람각에 올리는 공양물은 사찰에서 금하는 술이나 건어물 등이 포 함되어 있으며, 국사대신의 공양시간이 술시에서 해시인 점등도 불교 의식과 다른 점이다.

\section{4. 나가기}

가람의 한국민속적 요소와 의미를 가람각을 통하여 고찰하여 보았다.

한국은 가람 - 도량 - 경내를 구분 없이 사용하고 있지만, 경전을 통 하여 살펴본, 가람과 도량이란 용어는 분명한 사상적 차이를 나타내 고 있었다.

경전에서 설한 가람신으로, 가람18신과 마후라가왕 가람신, 두 부 류가 있는데, 이들 가람신은 공통적으로 정진수행을 강조하고 있다. 그런데, 가람18신은 나태한 수행자의 현보現報를 강조하고 있어, 민 
간신앙과의 습합의 맹아를 엿볼 수 있으며, 사신蛇神인 마후라가왕 가 람신은 한국의 터주신인 구렁이 신앙과도 관련성을 지닐 것으로 생각 한다. 이에 대한 고찰을 필요로 한다.

그러나, 중국은 두 부류의 가람신이 아닌, 도교의 토지신을 선종사원 에서 가람신으로 수용하였으며, 중국 가람신은 일본 선종사원으로 전 래되었다. 건장사에는 일본 최고最古의 가람신상 5 구가 현존하고 있 다. 하지만, 한국에는 중국 가람신상의 전래에 관한 기록이나 유형물 등의 문화적 흔적이 남아있지 않다.

한국 가람각의 특징은 가람신상과 가람탱화를 모시지 않고, 가람패 만 있는 것이다. 현재는 통도사와 해인사에 가람탱화가 있지만, 이는 해당 사찰 가람각에 적합하지 않음을 확인하였다. 가람패는 조선시대 성황신앙을 제도화하는 과정에서 신상을 모시지 않고 목패를 만들어 서 대신하였던 시대적 배경을 내포하고 있었다.

특히, 통도사는 한때 가람신상으로 모셨던 일본의 대흑천상을 유물 관으로 이전하였지만, 현재 봉안되어 있는 가람탱화에도 대흑천상이 그려져 있어, 봉안 여부에 대한 검토를 필요로 한다.

통도사의 말사인 표충사에는 내 - 외가람각 두 개의 전각이 있지만, 가람각에 대한 문헌기록이 없어 상세한 내용은 알 수 없다. 내가람각은 사명대사를 기리는 향사 때 공양을 올리고 간단히 법회를 갖으며, 외가 람각은 마을 사람들이 항시 기도를 올린다고 한다.

한편, 통도사와 표충사에서 사용하고 있는 '가람각'이라는 전각명은 경전에도 출전이 없고, 중국이나 일본에서도 사용된 적이 없다. 양국 兩國에서 사용한 가람당을 쓰지 않은 것은, 중국 가람신이 전래되지 않은 이유도 있겠지만, 그와 같은 관점보다는 성황당의 음사淫祀적이 고, 민간신앙적인 이미지와의 동격을 피하기 위함이었다는 해석이 더 
타당할 것이다.

해인사 국사단의 특징은 산신신앙과 신중신앙, 그리고 성황신앙이 중층으로 습합된 양상을 보이고 있는 점이다. 현재 정견모주를 탱화로 모시고 있는데, 이는 국사단 전각의 성격과 부합하지 않는다. 산신과 신중의 신격을 동시에 갖고 있는 국사대신을 모셨던 전통이 국사단의 위격을 제대로 갖게 하는 것이다. 이에 대해서는 통도사의 경우와 마찬 가지로 정견모주 탱화의 봉안여부에 대한 사중의 검토를 필요로 한다. 그리고, 일제강점기에 강대련스님이 국사단에 기부한 전답은 삼국시 대부터 시작된 위전位田이었다는 점에 대해서도 살펴보았다.

위의 고찰을 통하여, 가람각의 한국민속적 요소에 대해서는 가람패 봉안의 문제, 가람신상의 부재, 국사대신의 호칭, 고목나무와 토우 등 의 항목으로 살펴보았다.

가람신상의 부재는 건궁성주와 연관하여 고찰하였다. 가람신은 수 호신이면서도 신중이나 사천왕들보다 하위의 신격을 갖는다. 그러나, 가람신상을 모시지 않는다고 가람신을 부정하지 않으며, 가람각의 기 능이 상실되는 것도 아니다. 이와 같은 점들이 건궁성주와 너무도 흡 사하다.

또한, 국사대신의 '대신'은 당 - 송시대의 성황신이나 산신 등에 대 한 봉작封爵의 역사에서 유래하였다는 점, 가람각 주변의 고목나무가 신목일 가능성, 주술적 신앙의 상징물인 토우가 단위에 놓여있었다는 점 등도 가람각의 불교민속적인 면을 대변하고 있는 것이다. 그 외에 도, 가람각의 참배자가 대부분 무속인이며, 공양물에 술이나 건어물 등 이 포함되어 있고, 국사대신의 공양시간이 술시에서 해시라는 요소들 도 있다.

마지막으로, 향후는 민속불교적인 입장에서의 연구와, 전국의 가람 
각에 대한 종합적인 고찰, 그리고, 가람각을 영가각이라고도 하는 문제 등을 과제로 삼고자 한다. 특히, 영가각과의 관련성은 성황신앙과 밀 접한 관계성 때문이라고 보여지는데, 성황신앙에서는 마을의 유력자 가 죽으면 신격화하여 지방을 수호하는 수호신으로 삼았다. 이 수호신 들이 사후의 세계를 관장한다고 여겼던 사실이 순창과 순천지방에 남 아있는데, ${ }^{126)}$ 이러한 시대적 배경 때문에 가람각이 영가각의 역할도 겸 하게 되었다고 보아진다.

126) 각주40) 참조. 


\section{1. 경전}

『大莊嚴論經』권14(『대정장』4)

『妙法蓮華經』권6(『대정장』9)

『大方廣佛華嚴經』권1( 『대정장』9)

『大方廣佛華嚴經』권1 ( 대정장』10)

『七佛所說神呪經』권4(『대정장』21)

『陀羅尼雜集』권6(『대정장』21)

『新華嚴經論』 권11; 권33(『대정장』36)

『四分律刪繁補關行事鈔』권하(『대장경』40)

『集諸經禮懺儀』권상(『대정장』47)

『勅修百丈清規』 권2 ; 권3; 권5; 권7(『대정장』48)

『神僧傳』권5(『대정장』50)

宋高僧傳』권19( 『대정장』50)

『法華經傳記』권3(『대정장』51)

『景德傳燈錄』권27(『대정장』51)

『法苑珠林』 권38 ; 권39(『대정장』53)

『諸經要集』권3(『대정장』54)

『釋氏要覧』 권상 ; 권하( 『대정장』54)

『幻住庵清規』( 만자속장경』63)

『列祖提綱錄』권22(『만자속장경』64)

『法界聖凡水陸勝會修齋儀軌』권2( 만자속장경』74) 


\section{2. 원전}

한국학문헌연구소편, 『通度寺誌』, 아세아문화사, 1979년

동국대학교 불교문화연구원, 『조선불교통사』, 동국대학교 출판부, 2010년

\section{3. 사전}

『가산불교대사림』권1

망월불교대사전』 권1; 권4

\section{4. 단행본}

東京帝国大学工科大学, 『韓国の建築と芸術』建築文化, 1905

(韓国の建築と芸術刊行会，韓国の建築と芸術』,1988 복간본)

이지관, 『가야산해인지』, 가산불교문화연구원출판부, 1992

이상해, 『해인사건축도집』, 한샘, 1994

홍윤식 외, 『불교민속학의 체계』, 집문당, 1996

대한불교진흥원, 『월정사』, 활불교문화단, 2009

\section{4. 학술논문}

三山進，「伽藍神像考一鎌倉地方の作品を中心叫， 窪德忠，「台湾の土地神信仰」，『宗教㸴究』44-4, 日本宗教学会, 1971

- - 「土地神と土帝君」, 『宗教㸴究』45-3, 日本宗教学会, 1972

- - 「東アジアの土地神信仰」、『宗教研究』46-3, 日本宗教学会, 1973

酒井忠夫,「中国江南史上の道教信仰一特に土地神をめぐる文化の地域性」，『仏教の歴史と文 化』, 同朋舍, 1980

김갑동, 「고려시대의 성황신앙과 지방통지」, 『한국사연구』 74,1991

中世古祥道,「招宝七郎大権修理菩薩について」、『宗学研究』 35 , 曹洞宗総合研究センター, 1993 
加納寛，「タイ中央部都市土地神信仰の变遷にみる民鼻文化変容-祠・神体の形態変遷を中心 に」、東南アジア史学会会報』61, 東南アジア史学会, 1994

김갑동, 「고려시대 순창의 지방세력과 성황신앙」, 『한국사연구』97, 1997

서영대, 「한국과 일본의 성황신앙비교」, 『중국사연구』 12, 2001

이수자, 「구렁이업 신앙의 성격과 형성 기원 $1 」$ 『민속학술자료총서 세시풍속2』, 우리마당 터, 2002

노동명, 「고려시기 순천의 산신·성황신앙」, 『역사학보』174, 2002

김명자, 「가신신앙과 외래종교의 만남」, 『민속문화가 외래문화를 만나다』, 집문당, 2003

-_ 「경기지역의 터주신앙」, 『민속학술자료총서』5차, 우리마당터, 2003

二階堂善弘，「祠山張大帝考一伽藍神としての張大帝」，“關西大學中國文學會紀要』28, 関西大 学, 2007

「民間信仰における神形象の变化について-華光大帝と招宝七郎を例に」，『東アジア文 化交渉研究』1,関西大学, 2008

田中知佐子，「建長寺伽藍神像をめぐる一考察-中国風伽藍神像の系譜から」，『仏教芸術』301， 毎日新聞社, 2008

이기선,「가람각」, 『불교』672, 월간불교사, 2011.10.

통도사발행『가람각」, 『월간 보궁』 384, 2013.11.

広瀬良文，「中世禅宗の土地伽藍神について-建長寺・永平寺像を中心に」，『印仏学』，62-2， 2014

\section{5. 인터넷}

間宮士信等編，『新編相模国風土記稿』권78，「鎌倉郡」，（http://dl.ndl.go.jp/info:ndlijp/ pid/763970(일본국립국회도서관 디지털 컬렉션)) 『新編鎌倉志』 권3, 「建長寺」(http://dl.ndl. go.jp/info:ndljp/pid/2563543) 
